\title{
FORMULATION OF HAJRAL YAHUD PISHTI AND ITS IN VITRO ANTIUROLITHIATIC EFFECT
}

\author{
CHHAYA KUMARI, DILEEP SINGH BAGHEL*, BIMLESH KUMAR, SAURABH SINGH
}

School of Pharmaceutical Sciences, Lovely Professional University, Punjab, India. Email: baghel_12@rediffmail.com

Received: 30 October 2017, Revised and Accepted: 24 November 2017

\section{ABSTRACT}

Objectives: The objectives of this study were to formulate and analyze the physicochemical properties of hajral yahud pishti and its in vitro evaluation for antiurolithiatic effect.

Methods: Hajral yahud pishti was prepared using chandan arka, nagarmotha arka, and jala (water), respectively, as bhawana dravya. Physicochemical parameters were carried out using standard methods mentioned in official compendium of Ayurveda. In vitro antiurolithiatic activity of the prepared hajral yahud was done on artificially prepared urine.

Results: No significant variation was observed in the physicochemical analysis of all prepared samples in different concentrations, i.e., 100 , 200, 400,800 , and $1000 \mu \mathrm{L}$ of the hajral yahud pishti showed dose-dependent antiurolithiatic activity in prepared artificial urine $1000 \mu \mathrm{L}$ concentration exhibited $74.47 \%$ protection.

Conclusion: The prepared hajral yahud pishti gave protection against urolithiasis.

Keywords: Pishti, Hajral yahud, Antiurolithiatic, in vitro, Urolithiasis.

(C) 2018 The Authors. Published by Innovare Academic Sciences Pvt Ltd. This is an open access article under the CC BY license (http://creativecommons. org/licenses/by/4. 0/) DOI: http://dx.doi.org/10.22159/ajpcr.2018.v11i2.23385

\section{INTRODUCTION}

Hajral yahud was considered as another miracle of Allah's creations by the Unani writers [1,2], these stones are tiny ovular and resemble like the shape of olive fruits and their name is more than 1,000 years old, Sahib-ul-Qanoon wrote about them that triturated Hajar-alYahud is widely used in Unani medicine for dissolving kidney stones. Mutrakrichha (dysuria) means retention of urine, accompanied by painful micturition. It was considered to be the one of the important causes of all type of kidney stones [3-7]. Urolithiasis (Mutra ashmari) commonly known as kidney stones. It is basically urinary tract disorder which is characterized by the formation of stone in the kidneys. It occurs due to decreased volume of the urine or accumulation of stoneforming components such as calcium oxalates, cysteine, and xanthine which we used to take in our day-to-day meal [8-12]. These crystals get deposited in the form of precipitates in the basement of the loop of Henley, leading to the formation of renal calculi. These stones are responsible cause for the blood in urine associated with intense pain in the abdomen [13-15]. For the treatment of urolithiasis, many treatment modalities have been adopted using traditional as well as allopathic system of medicines, but the pathogenesis behind the stones is not always avoidable. Ayurvedic system of medicine exemplifies ahara dravyas as well as aushadh dravyas for the treatment of urolithiasis $[16,17]$. This present investigation was aimed to formulate the herbomineral formulation of Hajral yahud in pishti form and its in vitro evaluation for antiurolithiasis against $0.01 \mathrm{M}$ sodium oxalate in artificial urine $(\mathrm{AU})$.

\section{METHODS}

Procurement of materials

The drug hajral yahud was purchased from local market of Jalandhar, Punjab, and was authenticated by chemist in-charge, Herbal Health Research Consortium, Amritsar, under reference broacher number 01/2016/MIS/004 dated 10/02/2016. The plant samples (chandan and nagarmotha) were collected also from local market of Jalandhar, Punjab, and was identified and authenticated by Dr. Satiwinderjeet Kaur, Head, Department of Botanical and Environmental Sciences,
Guru Nanak Dev University Amritsar, Punjab, with reference broacher number 1452, dated 08.01.2016.

\section{Morphology [18]}

The morphological characters of herbal drug were studied using dissecting microscope and observed characters were tabulated (Table 1).

Preparation of chandan and nagarmotha arka by distillation [19-21] One part each of powder of nagarmotha and chandan was taken in two different round bottom flask (RBF), and further, eight parts of water were added in both RBF. The distillation assembly was assembled to prepare its arka.

\section{Preparation of hajral yahud pishti [22-24]}

Hajral yahud washed with hot water (5\% salt solution) followed by washing with cold water 4-5 times until the removal of salt, further dried under sun rays. The purified stones were crushed in iron mortar and pestle, then sieved it through 100 mesh size to get powder. The powder was triturated with chandan arka, nagarmotha arka, and distilled water to prepare 9 different samples of hajral yahud pishti. The prepared pishti was packed in a well-closed container.

Physicochemical evaluation [25-30]

Different physicochemical investigations of pishti and its raw materials were carried out using standard pharmacopeial methods including organoleptic parameters, determination foreign matter, loss on drying, total ash, acid insoluble ash, water-soluble extractive, alcohol-soluble extractive, and $\mathrm{pH}$ determinations as represented in Tables 2-4.

Determination of physical characteristics of powder [31] Physical characteristics such as bulk density, tapped density, Carr's compressibility index, and angle of repose were determined for the prepared pishti powder as represented in Table 5.

Infrared spectroscopy (Shimadzu) [32,33]

Infrared spectroscopy was performed and obtained spectra with values were represented in Table 6 and Figs. 1-9. 
In vitro antiurolithiatic study [34-37]

Preparation of $A U$

The AU was prepared according to the method Burns and Finlayson and had the following composition: Sodium chloride $105.5 \mathrm{mmol} / \mathrm{l}$, sodium phosphate $32.3 \mathrm{mmol} / 1$, sodium citrate $3.21 \mathrm{mmol} / \mathrm{l}$, magnesium sulfate $3.85 \mathrm{mmol} / 1$, sodium sulfate $16.95 \mathrm{mmol} / 1$, potassium chloride $63.7 \mathrm{mmol} / 1$, calcium chloride $4.5 \mathrm{mmol} / 1$, sodium oxalate $0.32 \mathrm{mmol} / 1$, ammonium hydroxide $17.9 \mathrm{mmol} / 1$, and ammonium chloride $0.0028 \mathrm{mmol} / 1$. The AU was prepared fresh each time and $\mathrm{pH}$ adjusted to 6.0 .

\section{Study without inhibitor}

A volume of $1.0 \mathrm{ml}$ of AU was transferred into the cell and $0.5 \mathrm{ml}$ of distilled water added to it and blank reading was taken. The $0.5 \mathrm{ml}$ of $0.01 \mathrm{M}$ sodium oxalate was added, to the previous volume, and the measurement is immediately started for $10 \mathrm{~min}$. For each experiment, six replicates were taken.

Study with inhibitor

The drug was dissolved in distilled water and filtered through membrane filter, and the concentration of 50,100,150, 200, and $250 \mu \mathrm{g} / \mathrm{ml}$ was obtained. A mixture of $1 \mathrm{ml}$ of $\mathrm{AU}$ and $0.5 \mathrm{ml}$ of drug

Table 1: Morphological characters of chandan and nagarmotha

\begin{tabular}{lll}
\hline Characters & Chandan (heart wood) & Nagarmotha (rhizomes) \\
\hline Color & Creamish brown & Dark brown \\
Odor & Aromatic & Aromatic \\
Taste & Sweetish & Bitter \\
Shape & Cylindrical & Unorganized \\
Size & $4.5-5 \mathrm{~cm}$ & $4-5.2 \mathrm{~cm}$ \\
Surface & Smooth & Rough \\
Fracture & Hard & Soft and fibrous \\
\hline
\end{tabular}

Table 2: Physicochemical evaluation of raw materials of hajral yahud pishti

\begin{tabular}{lllll}
\hline Parameters & Chandan & \multicolumn{3}{c}{ Nagarmotha } \\
\cline { 2 - 5 } & $\begin{array}{l}\text { Standard } \\
\text { value (\%) }\end{array}$ & $\begin{array}{l}\text { observed } \\
\text { value (\%) }\end{array}$ & $\begin{array}{l}\text { Standard } \\
\text { value (\%) }\end{array}$ & $\begin{array}{l}\text { observed } \\
\text { value (\%) }\end{array}$ \\
\hline FM & N.M.T 1 & 0.3 & N.M.T 2 & 0.5 \\
LOD & - & 11.8 & - & 8 \\
TA & N.M.T 1 & 0.9 & N.M.T 8 & 6.9 \\
AIA & N.M.T 0.2 & 0.1 & N.M.T 4 & 3.2 \\
WSE & N.L.T 1 & 12 & N.L.T 11 & 15.6 \\
ASE & N.L.T 8 & 10.4 & N.L.T 5 & 12.4 \\
\hline
\end{tabular}

FM: Foreign matter, LOD: Loss on drying at $105^{\circ} \mathrm{C}$, TA: Total ash, AIA: Acid insoluble ash, WSE: Water-soluble extractive, ASE: Alcohol-soluble extractive solution was versed in the cell. A blank reading was taken, and then, $0.5 \mathrm{ml}$ of $0.01 \mathrm{M}$ sodium oxalate solution was added and immediately the absorbance was measured for $10 \mathrm{~min}$ at $620 \mathrm{~nm}$. For each experiment, six replicates were taken. The percentage of inhibition was calculated using the following formula:

$\%$ inhibition $=\{1-[\mathrm{Si} / \mathrm{Sc}]\} \times 100$

Where

$\mathrm{Si}$ : Slope of graph in the presence of inhibitor (extract),

Sc: Slope of graph without inhibitor (control)

The obtained data are represented in Table 7.

Microscopic study [20,38,39]

The crystals of calcium oxalate (with and without inhibitors) were observed using a light microscope (Labmed) equipped with a digital camera. The photographs of $\mathrm{CaOx}$ were taken using the objective of $40 \times$ and eye piece of $10 \times$.

\section{Acid neutralizing capacity [40]}

The neutralization capacity of the compound is determined in terms of requirement of $0.5 \mathrm{~N}$ sodium hydroxide to neutralize $1 \mathrm{~g}$ of Hajral yahud pishti. Accurately weighed $100 \mathrm{mg}$ Hajral yahud pishti was taken and dissolved in $10 \mathrm{ml}$ of $3 \mathrm{~N} \mathrm{HCL}$. The solution was titrated with $0.5 \mathrm{~N}$ $\mathrm{NAOH}$ using phenolphthalein as indicator. A blank was also performed by titrating $10 \mathrm{ml}$ of $3 \mathrm{~N} \mathrm{HCL}$ (solution used for dissolving the sample) with $0.5 \mathrm{~N} \mathrm{NAOH}$. The difference between the two readings gives the amount of $0.5 \mathrm{~N}$ NAOH required for neutralizing $100 \mathrm{mg}$ Hajral yahud pishti (Table 8).

\section{Complexometric titration}

These type of titrations are those in which a complexing agent is used to estimate polyvalent ions. Take weighed amount of drug in conical flask and add $45 \mathrm{ml}$ distilled water, ammonia solution, drop of concentrated sulfuric acid and adjust pH 10, add solochrome black as indicator. Then, titrate with ethylenediaminetetraacetic acid starting point is red wine color then end point turned into green (Table 9).

\section{RESULTS}

Standardization of raw material

Morphological characters and physicochemical parameters were performed to check the quality of raw drugs used in formulation and compared with the values given in the Ayurvedic Pharmacopeia of India. The obtained results are represented in Tables 1 and 2.

\section{Standardization of formulation}

The bhawana process was done with different liquid media and time consumed are tabulated in Table 3. Physicochemical characterization of prepared hajral yahud pishti was performed which showed slight

Table 3: Time consumed for each Bhawana

\begin{tabular}{lllll}
\hline Batch & Bhawna (Time in $\mathbf{h}$ ) & Bhawna with Chandan arka & Bhawna with Nagarmotha arka & Bhawna with water \\
\hline 1 & 62 & 1 & 1 & 1 \\
2 & 73 & 1 & 1 & 1 \\
3 & 76 & 1 & 1 & 1 \\
\hline
\end{tabular}

Table 4: Physicochemical evaluation of formulation of hajral yahud pishti

\begin{tabular}{|c|c|c|c|c|c|c|c|c|c|c|c|c|}
\hline Parameters & $\mathrm{C} 1$ & $\mathrm{C} 2$ & C3 & Mean & N1 & N2 & N3 & Mean & W1 & W2 & W3 & Mean \\
\hline LOD & 0.49 & 0.47 & 0.45 & 0.47 & 0.39 & 0.72 & 0.82 & 0.64 & 1.52 & 1.14 & 0.79 & 1.15 \\
\hline $\mathrm{TA}$ & 59.3 & 57.6 & 61.4 & 59.43 & 58.4 & 68.76 & 64.35 & 63.84 & 58.84 & 56.66 & 55.43 & 56.98 \\
\hline AIA & 1.29 & 0.57 & 1.31 & 1.06 & 0.71 & 1.43 & 1.28 & 1.14 & 1.91 & 1.83 & 1.47 & 1.74 \\
\hline ASE & 2.03 & 1.64 & 1.98 & 1.88 & 1.15 & 4.46 & 4.74 & 3.45 & 6.02 & 8.20 & 1.93 & 5.38 \\
\hline WSE & 1.36 & 1.58 & 2.40 & 1.78 & 1.92 & 9.67 & 6.16 & 5.92 & 3.85 & 3.42 & 1.98 & 3.08 \\
\hline $\mathrm{pH}$ & 8.8 & 9.1 & 9.3 & 9.07 & 9.4 & 10.2 & 10.6 & 10.07 & 9.3 & 9.7 & 8.4 & 9.13 \\
\hline
\end{tabular}

LOD: Loss on drying at $105^{\circ} \mathrm{C}$, TA: Total ash, AIA: Acid insoluble ash, ASE: Alcohol-soluble extractive, WSE: Water-soluble extractive, IR: Infrared, C1-C3: Chandan Arka, N1-N3: Nagarmotha Arka, W1-W3: Water 
Table 5: Flow properties prepared hajral yahud pishti

\begin{tabular}{|c|c|c|c|c|c|c|c|c|c|c|c|c|}
\hline Parameters & C1 & $\mathrm{C} 2$ & C3 & Mean & N1 & N2 & N3 & Mean & W1 & $\mathbf{W} 2$ & w3 & Mean \\
\hline Bulk density & 0.3 & 0.4 & 0.3 & 0.33 & 0.4 & 0.4 & 0.3 & 0.36 & 0.6 & 0.5 & 0.3 & 0.46 \\
\hline Tapped density & 1.2 & 1.1 & 1 & 1.1 & 1.4 & 1.3 & 1.2 & 1.3 & 1 & 1.1 & 1.4 & 1.16 \\
\hline Carr's compressibility index & 0.72 & 0.63 & 0.7 & 0.68 & 0.71 & 0.69 & 0.75 & 0.72 & 0.4 & 0.54 & 0.78 & 0.57 \\
\hline Angle of repose & 32.3 & 31.45 & 30.4 & 31.38 & 34.60 & 33.21 & 34.12 & 33.98 & 28.81 & 30.12 & 31.4 & 30.11 \\
\hline
\end{tabular}

C1-C3: Chandan Arka, N1-N3: Nagarmotha Arka, W1-W3: Water

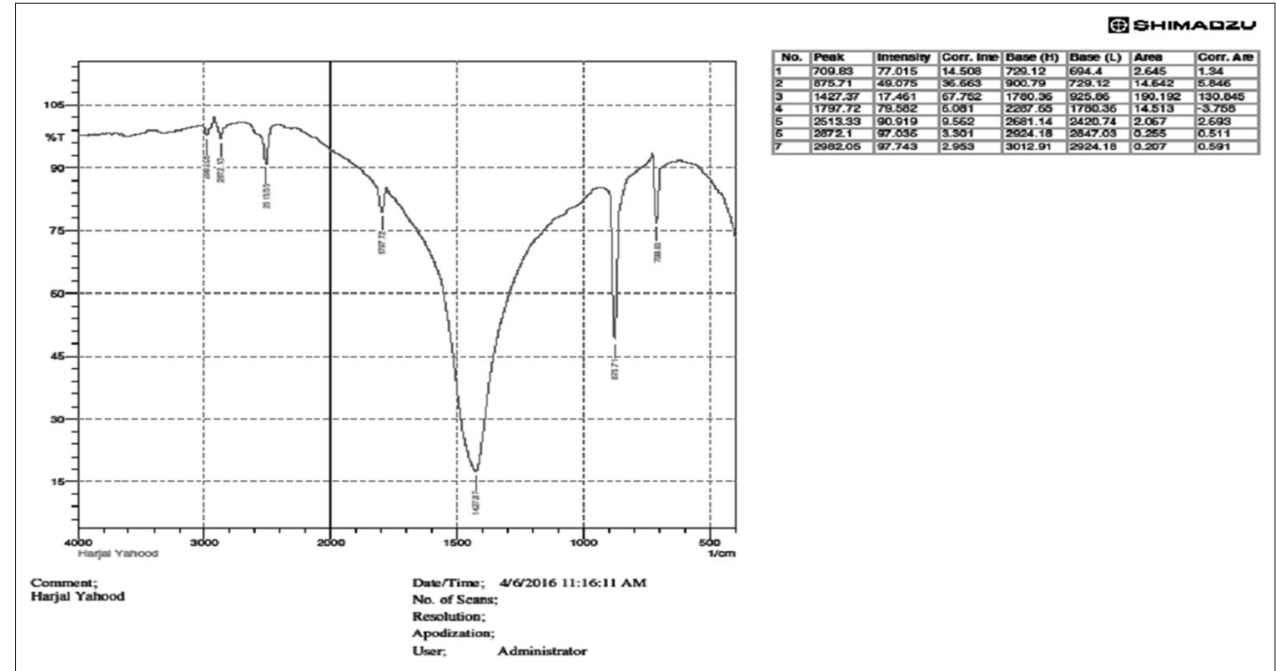

Fig. 1: Infrared hajral yahud (Chandan 1)

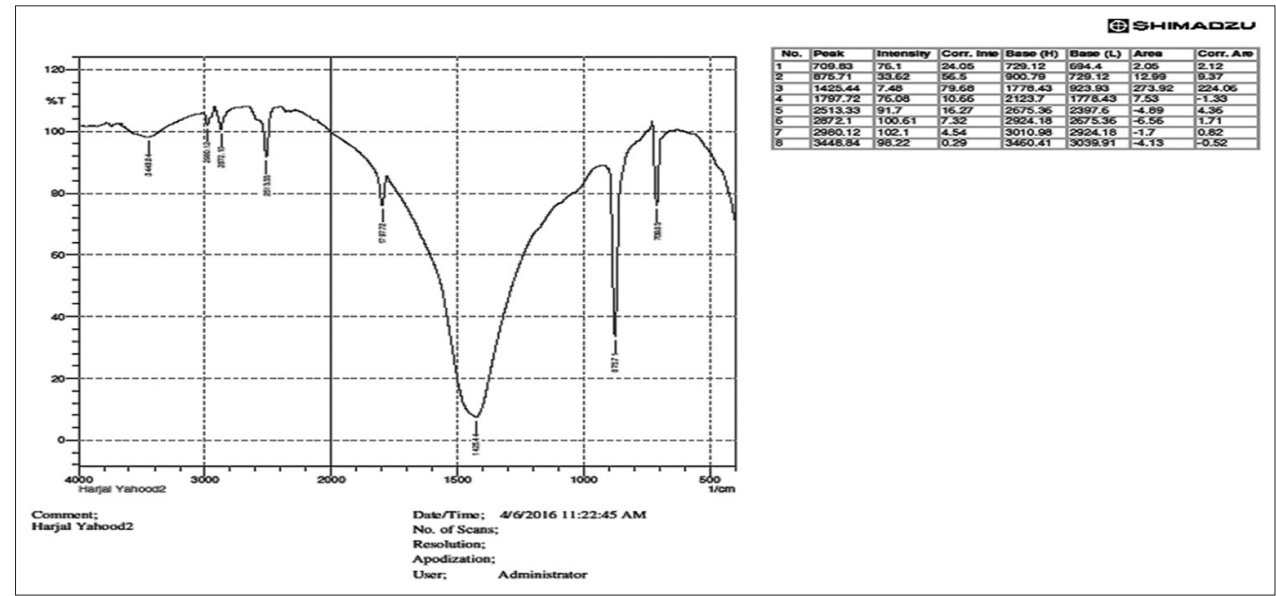

Fig. 2: Infrared hajral yahud (Chandan 2)

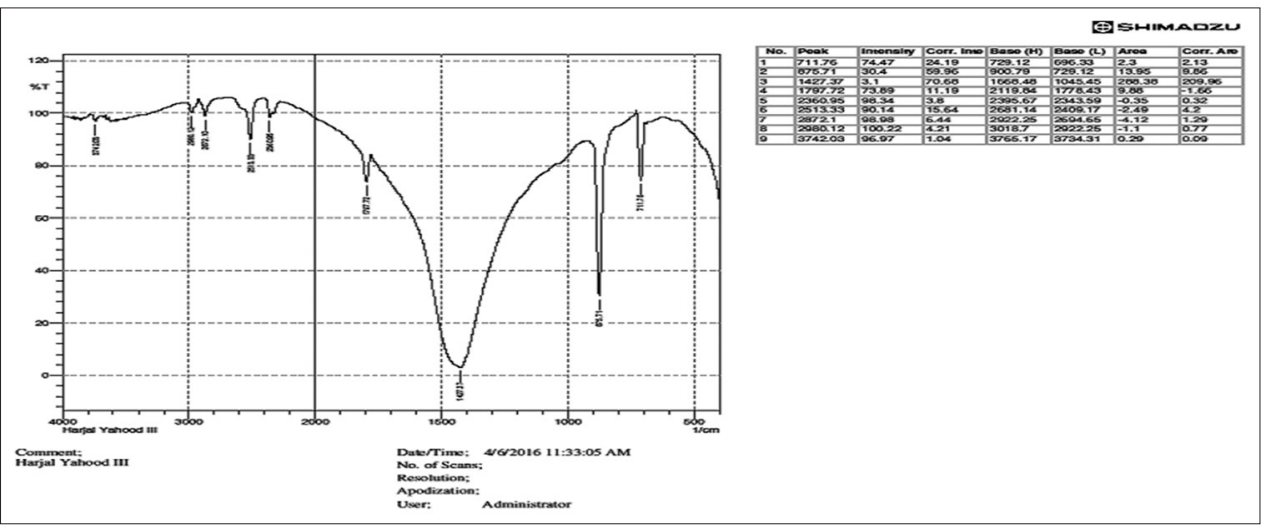

Fig. 3: Infrared hajral yahud (Chandan 3) 


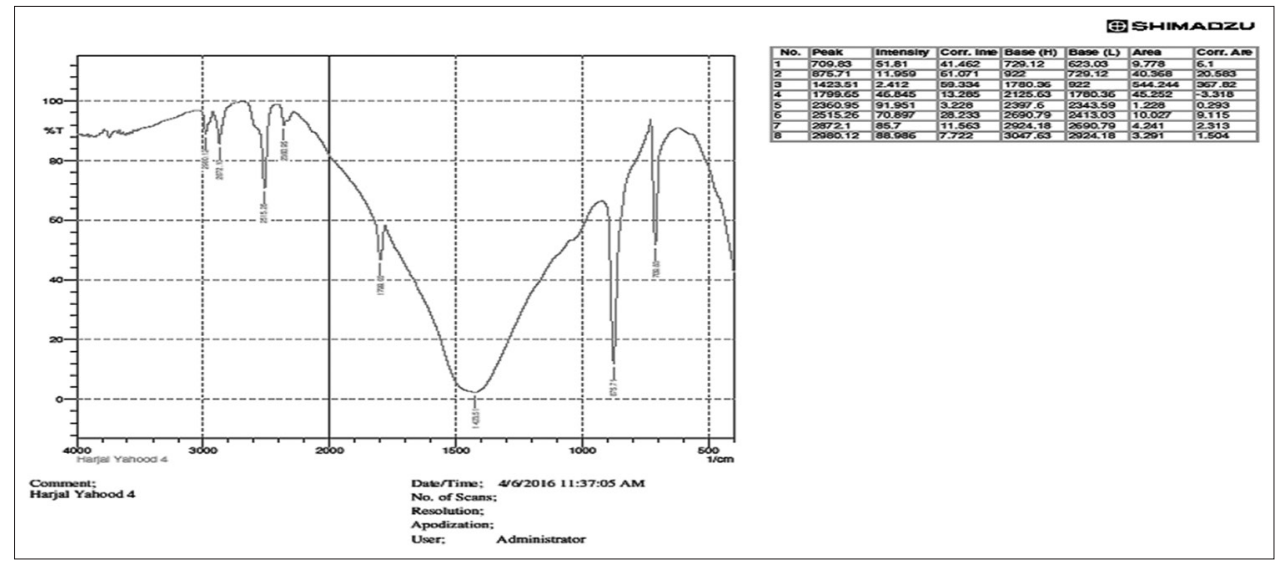

Fig. 4: Infrared hajral yahud (Nagarmotha 1)

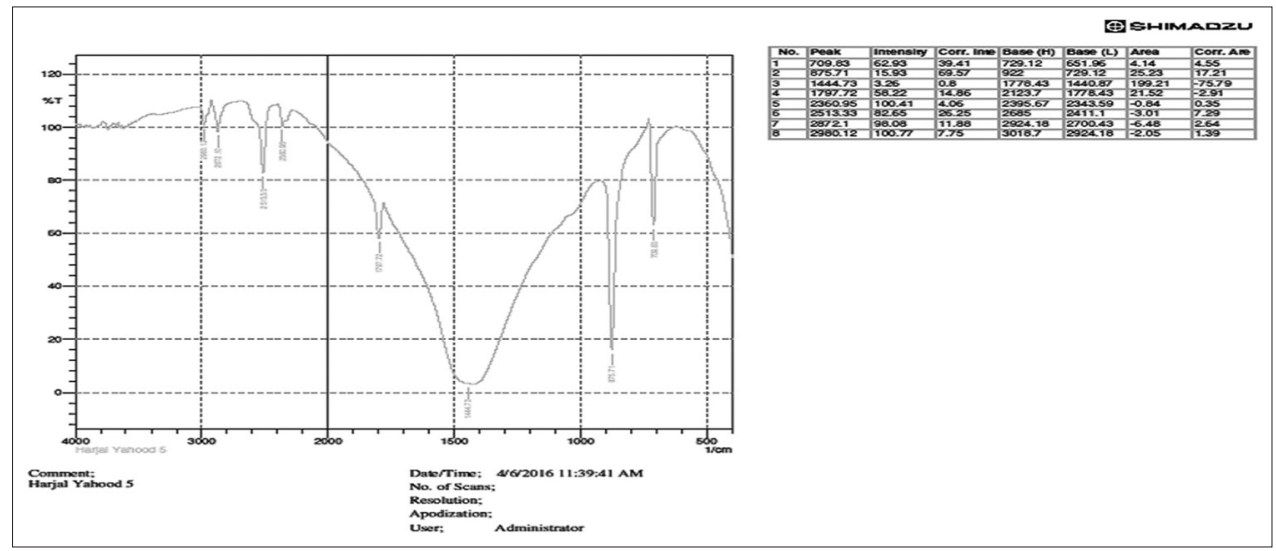

Fig. 5: Infrared hajral yahud (Nagarmotha 2)

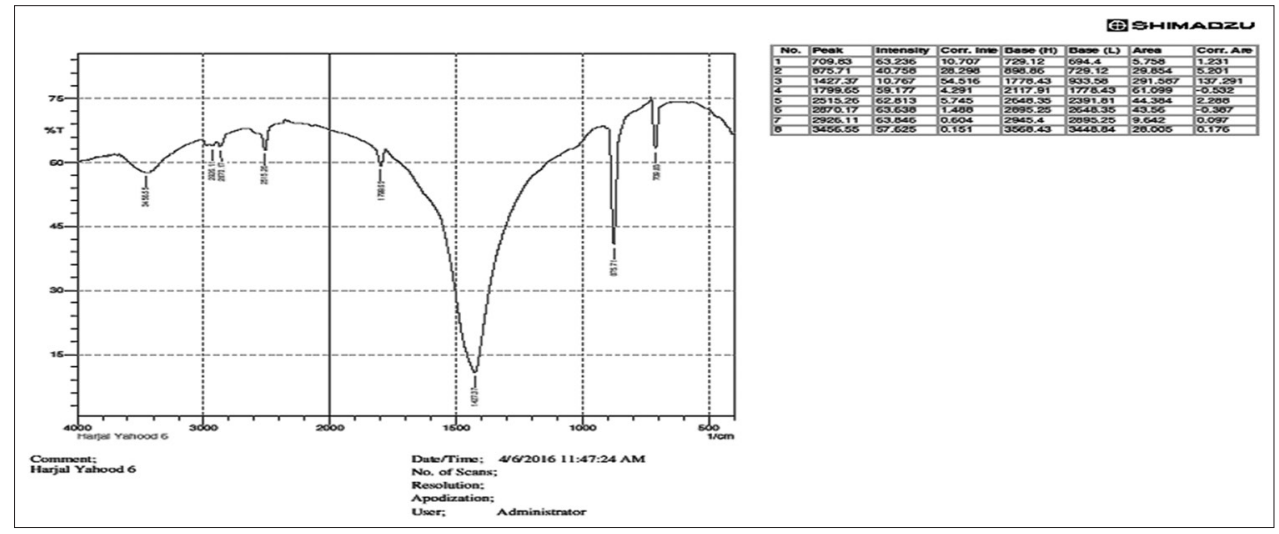

Fig. 6: Infrared hajral yahud (Nagarmotha 3)

difference in the readings of prepared batches of hajral yahud pishti, which suggests that the liquid mediums does not affect the formulation physically, and therefore, the method preparation could be planned using any of the liquid mediums according to the availability. The obtained value is represented in Table 4.

\section{Infrared spectroscopy (Shimadzu)}

Infrared spectroscopy was performed and observed major peaks are in the same range which confirm the presence of calcium carbonate, but the liquid mediums used were not differentiated by the IR, may be due to the evaporation of added liquid mediums during levigation process. The obtained peaks and intensity are represented in Table 6 and spectra is represented in Figs. 1-9.
Flow properties prepared hajral yahud pishti

Bulk density, tapped density, Carr's compressibility index, and angle of repose were found in limits which implies that the formulation hajral yahud pishti has good flow properties and will not affect the formulation during mixing, packaging, and transportation. The data related to flow properties are represented in Table 5.

\section{Determination of particle size}

Two methods were used for determining the particle size of prepared hajral yahud pishti batches. Both the methods were performed manually. From the microscopy, the particle size was found to be in the range of $0.3-0.5 \mathrm{~mm}$, while from the sieving method, maximum particles were passed through from mesh size 120 which indicates 
Table 6: Infrared spectroscopy

\begin{tabular}{|c|c|c|c|c|c|c|c|c|}
\hline Sample & No. & Peak & Intensity & Corr. Inte & Base $(\mathrm{H})$ & Base (L) & Area & $\begin{array}{l}\text { Corr. } \\
\text { Are }\end{array}$ \\
\hline \multirow[t]{6}{*}{ C 1} & 1 & 709.83 & 77.015 & 14.508 & 729.12 & 694.4 & 2.645 & 1.34 \\
\hline & 2 & 875.71 & 49.075 & 36.663 & 900.79 & 729.12 & 14.642 & 5.846 \\
\hline & 3 & 1427.37 & 17.461 & 67.752 & 1780.36 & 925.86 & 190.192 & 130.845 \\
\hline & 4 & 1797.72 & 79.582 & 6.081 & 2287.65 & 1780.36 & 14.513 & -3.758 \\
\hline & 5 & 2513.33 & 90.919 & 9.562 & 2681.14 & 2420.74 & 2.067 & 2.693 \\
\hline & 6 & 2872.1 & 97.036 & 3.301 & 2924.18 & 2847.03 & 0.255 & 0.511 \\
\hline \multirow[t]{8}{*}{ C 2} & 1 & 709.83 & 76.1 & 24.05 & 729.12 & 694.4 & 2.05 & 2.12 \\
\hline & 2 & 875.71 & 33.62 & 56.5 & 900.79 & 729.12 & 12.99 & 9.37 \\
\hline & 3 & 1425.44 & 7.48 & 79.68 & 1778.43 & 923.93 & 273.92 & 224.06 \\
\hline & 4 & 1797.72 & 76.08 & 10.66 & 2123.7 & 1778.43 & 7.53 & -1.33 \\
\hline & 5 & 2513.33 & 91.7 & 16.27 & 2675.36 & 2397.6 & -4.89 & 4.36 \\
\hline & 6 & 2872.1 & 100.61 & 7.32 & 2924.18 & 2675.36 & -6.56 & 1.71 \\
\hline & 7 & 2980.12 & 102.1 & 4.54 & 3010.98 & 2924.18 & -1.7 & 0.82 \\
\hline & 8 & 3448.84 & 98.22 & 0.29 & 3460.41 & 3039.91 & -4.13 & -0.52 \\
\hline \multirow{8}{*}{ C 3} & 2 & 875.71 & 30.4 & 59.96 & 900.79 & 729.12 & 13.95 & 9.86 \\
\hline & 3 & 1427.37 & 3.1 & 70.68 & 1668.48 & 1045.45 & 288.38 & 209.96 \\
\hline & 4 & 1797.72 & 73.89 & 11.19 & 2119.84 & 1778.43 & 9.88 & -1.66 \\
\hline & 5 & 2360.95 & 98.34 & 3.8 & 2395.67 & 2343.59 & -0.35 & 0.32 \\
\hline & 6 & 2513.33 & 90.14 & 15.64 & 2681.14 & 2409.17 & -2.49 & 4.2 \\
\hline & 7 & 2872.1 & 98.98 & 6.44 & 2922.25 & 2694.65 & -4.12 & 1.29 \\
\hline & 8 & 2980.12 & 100.22 & 4.21 & 3018.7 & 2922.25 & -1.1 & 0.77 \\
\hline & 9 & 3742.03 & 96.97 & 1.04 & 3765.17 & 3734.31 & 0.29 & 0.09 \\
\hline \multirow[t]{8}{*}{ N 1} & 1 & 709.83 & 51.81 & 41.462 & 729.12 & 623.03 & 9.778 & 6.1 \\
\hline & 2 & 875.71 & 11.959 & 61.071 & 922 & 729.12 & 40.368 & 20.583 \\
\hline & 3 & 1423.51 & 2.412 & 59.334 & 1780.36 & 922 & 544.244 & 367.82 \\
\hline & 4 & 1799.65 & 46.845 & 13.285 & 2125.63 & 1780.36 & 45.252 & -3.318 \\
\hline & 5 & 2360.95 & 91.951 & 3.228 & 2397.6 & 2343.59 & 1.228 & 0.293 \\
\hline & 6 & 2515.26 & 70.897 & 28.233 & 2690.79 & 2413.03 & 10.027 & 9.115 \\
\hline & 7 & 2872.1 & 85.7 & 11.563 & 2924.18 & 2690.79 & 4.241 & 2.313 \\
\hline & 8 & 2980.12 & 88.986 & 7.722 & 3047.63 & 2924.18 & 3.291 & 1.504 \\
\hline \multirow[t]{6}{*}{ N 2} & 1 & 709.83 & 62.93 & 39.41 & 729.12 & 651.96 & 4.14 & 4.55 \\
\hline & 4 & 1797.72 & 58.22 & 14.86 & 2123.7 & 1778.43 & 21.52 & -2.91 \\
\hline & 5 & 2360.95 & 100.41 & 4.06 & 2395.67 & 2343.59 & -0.84 & 0.35 \\
\hline & 6 & 2513.33 & 82.65 & 26.25 & 2685 & 2411.1 & -3.01 & 7.29 \\
\hline & 7 & 2872.1 & 98.08 & 11.88 & 2924.18 & 2700.43 & -6.48 & 2.64 \\
\hline & 8 & 2980.12 & 100.77 & 7.75 & 3018.7 & 2924.18 & -2.05 & 1.39 \\
\hline \multirow[t]{8}{*}{ N 3} & 1 & 709.83 & 63.236 & 10.707 & 729.12 & 694.4 & 5.758 & 1.231 \\
\hline & 2 & 875.71 & 40.758 & 28.298 & 898.86 & 729.12 & 29.854 & 5.201 \\
\hline & 3 & 1427.37 & 10.767 & 54.516 & 1778.43 & 933.58 & 291.587 & 137.291 \\
\hline & 4 & 1799.65 & 59.177 & 4.291 & 2117.91 & 1778.43 & 61.099 & -0.532 \\
\hline & 5 & 2515.26 & 62.813 & 5.745 & 2648.35 & 2391.81 & 44.384 & 2.288 \\
\hline & 6 & 2870.17 & 63.638 & 1.488 & 2895.25 & 2548.35 & 43.56 & -0.387 \\
\hline & 7 & 2926.11 & 63.846 & 0.604 & 2945.4 & 2895.25 & 9.642 & 0.097 \\
\hline & 8 & 3456.55 & 57.625 & 0.151 & 3568.43 & 3448.84 & 28.005 & 0.176 \\
\hline \multirow[t]{9}{*}{ W 1} & 1 & 399.28 & 54.128 & 0 & 565.16 & 399.28 & 33.277 & -2.669 \\
\hline & 2 & 711.76 & 53.591 & 14.851 & 729.12 & 694.4 & 7.599 & 1.878 \\
\hline & 3 & 875.71 & 28.932 & 33.062 & 900.79 & 729.12 & 39.419 & 7.362 \\
\hline & 4 & 1427.37 & 14.925 & 42.173 & 1778.43 & 922 & 364.772 & 159.754 \\
\hline & 5 & 1799.65 & 48.757 & 5.984 & 2117.91 & 1778.43 & 78.648 & -0.963 \\
\hline & 6 & 2515.26 & 54.864 & 8.346 & 2650.28 & 2395.67 & 54.483 & 3.707 \\
\hline & 7 & 2872.1 & 57.446 & 2.136 & 2897.18 & 2650.28 & 52.661 & -0.445 \\
\hline & 8 & 2980.12 & 58.205 & 1.294 & 3009.05 & 2943.47 & 15.09 & 0.26 \\
\hline & 9 & 3458.48 & 53.675 & 0.026 & 3462.34 & 3448.84 & 3.647 & 0.002 \\
\hline \multirow[t]{9}{*}{ W 2} & 1 & 709.83 & 50.57 & 12.218 & 729.12 & 624.96 & 23.611 & 2.36 \\
\hline & 2 & 875.71 & 30.717 & 25.288 & 900.79 & 729.12 & 45.978 & 6.314 \\
\hline & 3 & 1425.44 & 9.142 & 43.235 & 1780.36 & 920.08 & 390.891 & 151.953 \\
\hline & 4 & 1799.65 & 46.638 & 4.072 & 2119.64 & 1780.36 & 91.126 & -0.831 \\
\hline & 5 & 2364.81 & 56.416 & 0.907 & 2395.67 & 2345.52 & 12.198 & 0.132 \\
\hline & 6 & 2515.26 & 51.525 & 6.136 & 2650.28 & 2395.67 & 63.964 & 3.023 \\
\hline & 7 & 2870.17 & 52.581 & 1.579 & 2895.25 & 2650.28 & 62.139 & -0.567 \\
\hline & 8 & 2924.18 & 52.585 & 0.915 & 2947.33 & 2895.25 & 14.314 & 0.181 \\
\hline & 9 & 3456.55 & 48.566 & 0.114 & 3583.86 & 3448.54 & 41.553 & 0.24 \\
\hline \multirow[t]{3}{*}{ W 3} & 1 & 709.83 & 37.943 & 25.482 & 729.12 & 644.25 & 21.785 & 4.732 \\
\hline & 2 & 875.71 & 8.819 & 43.6 & 920.08 & 729.12 & 65.818 & 17.584 \\
\hline & 3 & 1442.8 & 2.066 & 0.222 & 1778.43 & 1440.87 & 287.933 & -63.468 \\
\hline
\end{tabular}


Table 6: (Continued)

\begin{tabular}{|c|c|c|c|c|c|c|c|c|}
\hline Sample & No. & Peak & Intensity & Corr. Inte & Base (H) & Base (L) & Area & $\begin{array}{l}\text { Corr. } \\
\text { Are }\end{array}$ \\
\hline & 4 & 1799.65 & 32.112 & 8.808 & 2119.84 & 1778.43 & 109.382 & -2.491 \\
\hline & 5 & 2515.26 & 42.767 & 14.519 & 2654.14 & 2395.67 & 70.263 & 7.62 \\
\hline & 6 & 2872.1 & 47.321 & 3.573 & 2895.25 & 2654.14 & 64.704 & -1.112 \\
\hline & 7 & 2924.18 & 48.45 & 1.41 & 2945.4 & 2895.25 & 15.419 & 0.286 \\
\hline & 8 & 2980.12 & 49.062 & 1.231 & 3026.41 & 2964.69 & 18.03 & 0.01 \\
\hline & 9 & 3443.05 & 43.628 & 0.135 & 3448.84 & 3026.41 & 133.068 & -1.624 \\
\hline
\end{tabular}

IR: Infrared spectroscopy, C1-C3: Chandan Arka, N1-N3: Nagarmotha Arka, W1-W3: Water

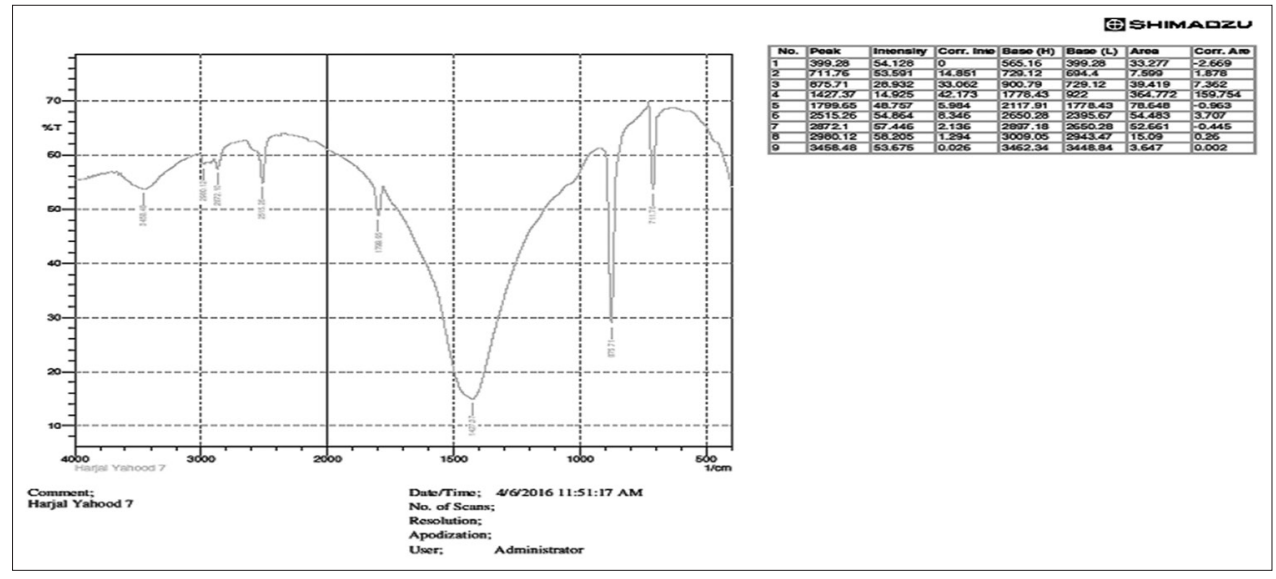

Fig. 7: Infrared hajral yahud (Water 1)

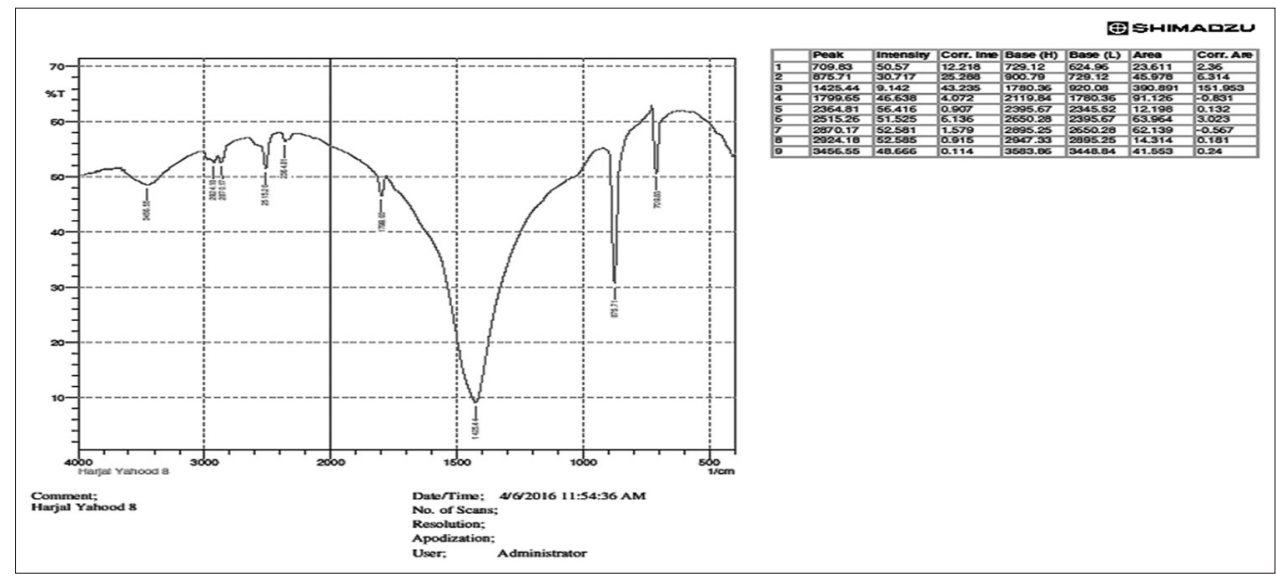

Fig. 8: Infrared hajral yahud (Water 2)

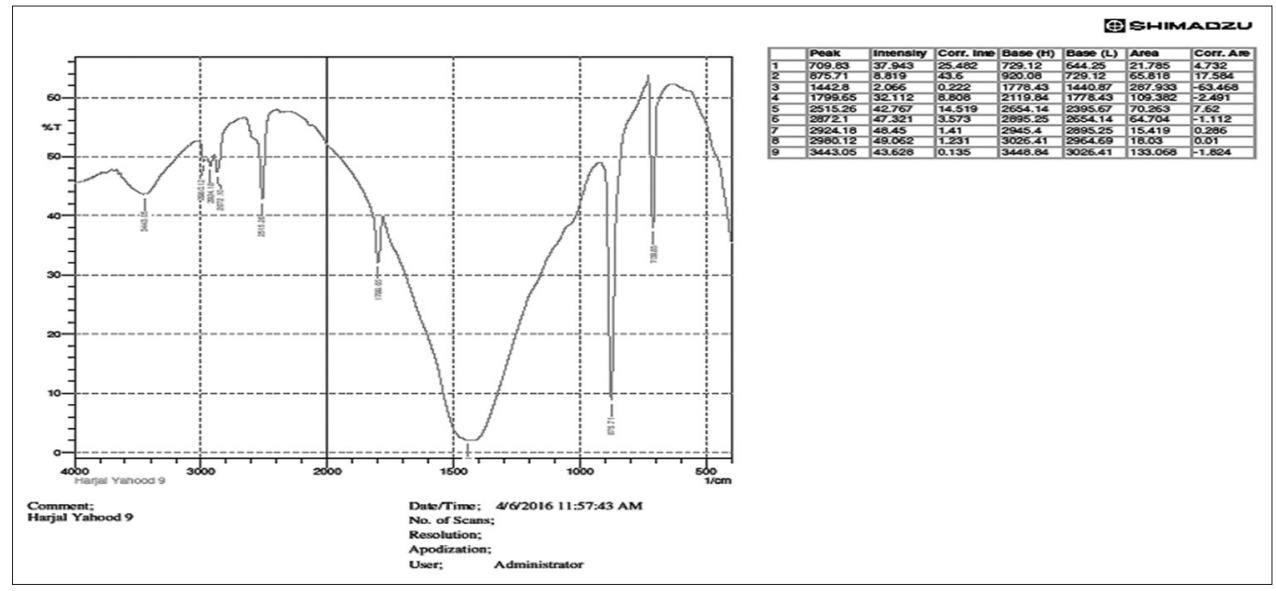

Fig. 9: Infrared hajral yahud (water 3) 


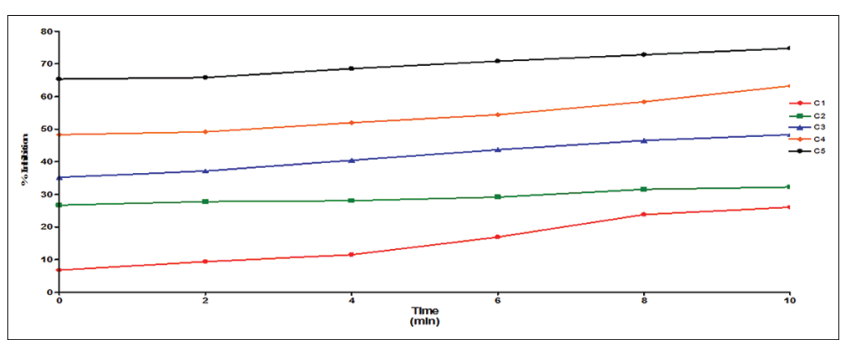

Fig. 10: Percentage inhibition with respect to time

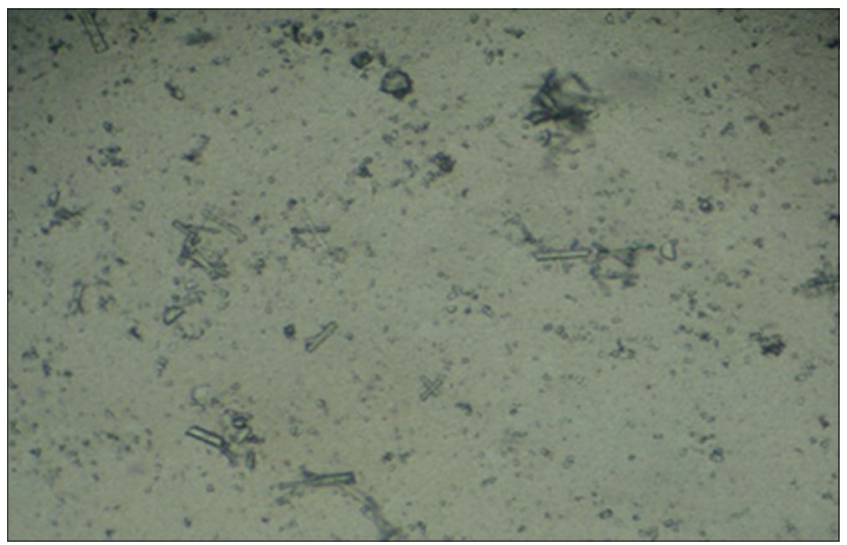

Fig. 11: Crystal growth in AU preparation

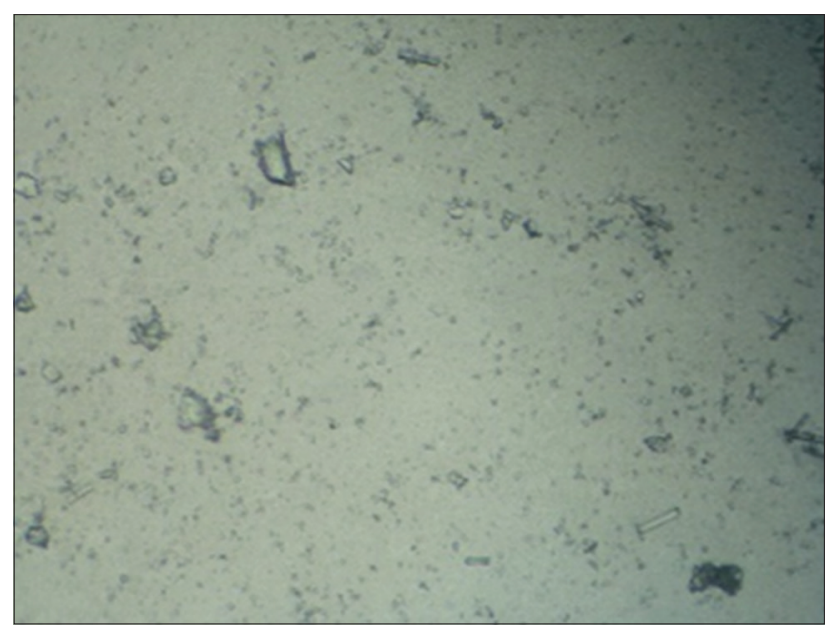

Fig. 12: Crystal inhibition in $100 \mu \mathrm{g} / \mathrm{ml}$ drug sample

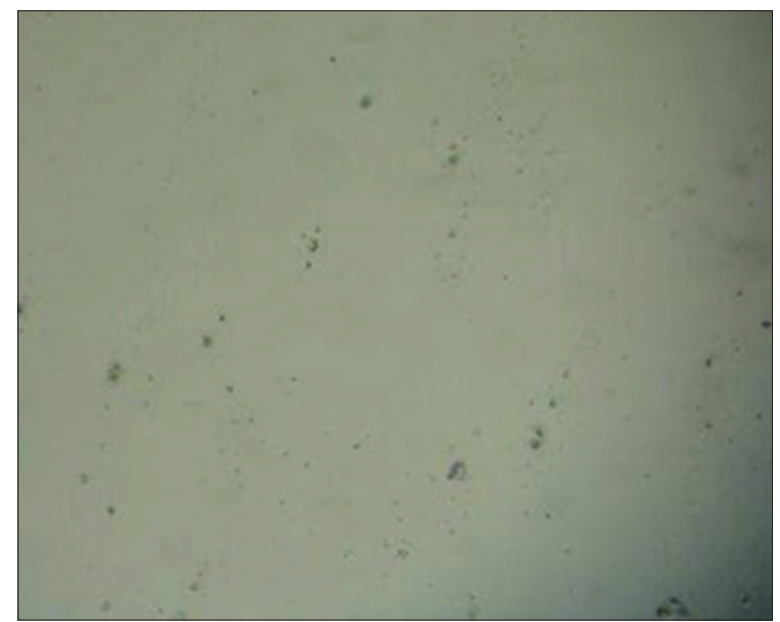

Fig. 13: Crystal inhibition in $100 \mu \mathrm{g} / \mathrm{ml}$ drug sample
Table 7: \% inhibition of Hajral Yahud Pishti with respect to time

\begin{tabular}{|c|c|c|c|c|c|}
\hline $\begin{array}{l}\text { Time in } \\
\text { minutes }\end{array}$ & $\begin{array}{l}100 \\
\mu \mathrm{g} / \mathrm{ml}\end{array}$ & $\begin{array}{l}200 \\
\mu \mathrm{g} / \mathrm{ml}\end{array}$ & $\begin{array}{l}400 \\
\mu \mathrm{g} / \mathrm{ml}\end{array}$ & $\begin{array}{l}800 \\
\mu \mathrm{g} / \mathrm{ml}\end{array}$ & $1000 \mu \mathrm{g} / \mathrm{ml}$ \\
\hline \multicolumn{6}{|c|}{$\begin{array}{l}\% \\
\text { inhibition }\end{array}$} \\
\hline 0 & 6.8182 & 26.705 & 35.23 & 48.3 & 65.34 \\
\hline 2 & 9.4017 & 27.778 & 37.18 & 49.15 & 65.81 \\
\hline 4 & 11.517 & 28.09 & 40.45 & 51.97 & 68.54 \\
\hline 6 & 16.926 & 29.188 & 43.7 & 54.4 & 70.81 \\
\hline 8 & 23.84 & 31.572 & 46.52 & 58.38 & 72.81 \\
\hline 10 & 26.037 & 32.258 & 48.27 & 63.25 & 74.47 \\
\hline
\end{tabular}

that the particle size of the prepared formulation was fine enough to produce therapeutic efficacy.

\section{Acid neutralizing capacity for prepared hajral yahud pishti}

An average of $0.26 \mathrm{mg} \mathrm{NAOH}$ was required to neutralize $100 \mathrm{mg}$ of hajral yahud pishti. The obtained data are represented in Table 8.

\section{Complexometric titrations for prepared hajral yahud pishti}

An average of $0.24 \mathrm{~g}$ of calcium was found in $1 \mathrm{~g}$ of the Hajral yahud Pishti. The obtained data are represented in Table 9.

\section{In vitro study}

In all the treatments, concentration-dependent initial steep rising in turbidity (nucleation) followed by decrease turbidity (aggregation) was seen and with the time \% inhibition also increases. The last two concentrations showed the maximum percentage of inhibition which implies that the drug is showing positive response toward antiurolithiatic activity in the in vitro studies. The data of inhibition in percentage are represented in Table 7 and the graph of inhibition in percentage is represented in Fig. 10. The microscopic images of crystal growth in $\mathrm{AU}$ and their inhibition in construction of $100 \mu \mathrm{g} / \mathrm{ml}$ and 1000 mg/ml are shown in Figs. 11-13.

\section{DISCUSSION}

In the present investigation, Hajral yahud pishti was evaluated for its physicochemical parameters and antiurolithiatic activity. Hajral yahud pishti was prepared using different liquid mediums. The physicochemical parameters were performed for the prepared formulation for three different batches treated with different liquid mediums, i.e., Chandan Arka, Nagarmotha Arka, and water for the 9 samples, respectively, but no significant variation was observed which indicates that there is not much effect of the liquid medium physically. In the same manner, the analytical parameters such as total ash, acid insoluble ash, alcohol-soluble extractive, water-soluble extractives, and IR were also performed which also not showed remarkable variations in functional groups. During the in vitro studies, the crystals were observed in the prepared sample of urine when mixed with sodium oxalate when observed under microscope. These crystals were found decreasing due to the addition of drug which shows that the drug is helpful in breaking crystals. In vitro studies were observed under ultraviolet spectrophotometer (Shimadzu 1800) when viewed under $620 \mathrm{~nm}$ with different dilutions without and with the drug having 100 , $200,400,800$, and $1000 \mu \mathrm{l}$, respectively, with time gap of $0,2,4,6,8$, and 10 min showed maximum $74.77 \%$ drug inhibition in the highest concentration.

\section{CONCLUSION}

The physicochemical parameters was performed and no significant variation was observed in all the prepared batches which was prepared using different rations of herb and concentration of water. IR study was also carried out to find functional groups in the prepared pishti samples, all the prepared batches showed the presence of calcium. Spectral analysis showed that there is no alteration in primary composition of hajral yahud. In vitro antiurolithiatic activity 
Table 8: Readings of acid neutralizing capacity for prepared hajral yahud pishti

\begin{tabular}{|c|c|c|c|c|c|c|c|c|c|c|c|}
\hline C1 & $\mathrm{C} 2$ & C3 & Mean & N1 & N2 & N3 & Mean & W1 & W2 & W3 & Mean \\
\hline 14.5 & 14.1 & 15.1 & 14.57 & 13.5 & 11.6 & 13.8 & 12.97 & 15.1 & 13.4 & 14.7 & 14.4 \\
\hline 15.5 & 13.8 & 15.2 & 14.93 & 13.6 & 11.6 & 12.6 & 12.6 & 15.4 & 13.2 & 14.5 & 14.37 \\
\hline 13.4 & 14.1 & 14.9 & 14.13 & 14.1 & 11.4 & 13.5 & 13 & 15.8 & 13.1 & 13.6 & 14.17 \\
\hline
\end{tabular}

C1-C3: Chandan Arka, N1-N3: Nagarmotha Arka, W1-W3: Water

Table 9: Complexometric titrations for prepared hajral yahud pishti

\begin{tabular}{|c|c|c|c|c|c|c|c|c|c|c|c|}
\hline C1 & $\mathrm{C} 2$ & C3 & Mean & N1 & N2 & N3 & Mean & W1 & W2 & W3 & Mean \\
\hline 5.8 & 6.1 & 6.4 & 6.1 & 5.4 & 5.1 & 5.4 & 5.3 & 4.7 & 4.9 & 5.2 & 4.93 \\
\hline 5.3 & 5.6 & 5.8 & 5.57 & 5.6 & 4.8 & 6.2 & 5.53 & 4.4 & 5.3 & 4.6 & 4.77 \\
\hline 6.8 & 5.5 & 6.1 & 6.13 & 4.8 & 5.7 & 5.3 & 5.27 & 4.1 & 4.7 & 4.5 & 4.43 \\
\hline
\end{tabular}

C1-C3: Chandan Arka, N1-N3: Nagarmotha Arka, W1-W3: Water

was performed for the all prepared batches using $\mathrm{AU}$, the crystal inhibition capacity was observed through optical microscopy in all the batches, so it is concluded that all the prepared batches of hajral yahud pishti at different concentrations, i.e., 100, 200, 400, 800, and $1000 \mu \mathrm{L}$ showed dose-dependent antiurolithiatic activity in prepared AU and $1000 \mu \mathrm{L}$ concentration exhibited maximum $74.47 \%$ protection.

\section{ACKNOWLEDGMENT}

The authors wish to express their sincere thanks to Professor (Dr.) Monica Gulati, Sr. Dean, School of Pharmaceutical Sciences, Lovely Professional University, Phagwara, Punjab, for guidance and support.

\section{AUTHORS CONTRIBUTION}

Chhaya Kumari: Principal investigator, performed preparation and analysis on all samples, interpreted data, write manuscript. Dileep Singh Baghel: Guide, supervised development of work, helped in data interpretation, manuscript evaluation and acted as corresponding author. Bimlesh Kumar: Helped to evaluate and edit the manuscript. Saurabh Singh: Helped to evaluate and edit the manuscript.

\section{CONFLICTS OF INTERESTS}

None Declared.

\section{REFERENCES}

1. Ahmed S, Hasan M. Muslim heritage in medicine: A concise review on Greco-Arabic contribution. J Pharmacogn Phytochem 2016;5:273-83.

2. Rajesh. Study of hasate Kulya (Renal Calculus) with therapeutic evaluation of unani formulation (Sufoof Hajrul Yahud) in its management. Int J Sci Res 2016;5:268-71.

3. Shastri S. Agnivesha Charaka Samhita. Chikitsa Sthana 26/599. Varanasi: Chaukhamba Bharti Academy; 2006.

4. Sushruta. Sushruta Samhita. Sutra Sthana 33/126. Varanasi: Chaukhambha Sanskrit Sansthan; 2005.

5. Sodimbaku V, Pujari L. Urolithiasis-an updated review over genetics, pathophysiology and its clinical management. Int J Pharm Pharm Sci 2014;6:23-31

6. Moe OW. Kidney stones: Pathophysiology and medical management. Lancet 2006;367:333-44

7. Evan A, Lingeman J, Coe FL, Worcester E. Randall's plaque: Pathogenesis and role in calcium oxalate nephrolithiasis. Kidney Int 2006;69:1313-8

8. Stamatelou KK, Francis ME, Jones CA, Nyberg LM, Curhan GC. Time trends in reported prevalence of kidney stones in the United States: 1976-1994. Kidney Int 2003;63:1817-23.

9. Mohanty NK, Nayak RL, Patki PS. Safety and efficacy of an ayurvedic formulation cystone in management of ureteric calculi: A prospective randomized placebo controlled study. Am J Pharm Toxicol 2010;5:58-64.

10. Shanmugapriya J, Kumar SS. A prospective study on quality of life in patients with urinary calculi. Asian J Pharm Clin Res 2017;10:191-3.
11. Coe FL, Evan A, Worcester E. Kidney stone disease. J Clin Invest 2005;115:2598-608.

12. Prasad K, Sujatha D, Bharathi K. Herbal drugs in urolithiasis - A review. Phcog Rev 2007;1:175-9.

13. Parks JH, Coward M, Coe FL. Correspondence between stone composition and urine super saturation in nephrolithiasis. Kidney Int 1997;51:894-900.

14. Khan SR. Calcium phosphate/calcium oxalate crystal association in urinary stones: Implications for heterogeneous nucleation of calcium oxalate. J Urol 1997;157:376-83.

15. Mustapha B, Hanane B, Idrissi M, Benramdane Larbi OB, Mustapha D. In vitro effect of acetylsalicylic acid on calcium oxalate crystallization: An approach to antilithiasis. Int J Pharm Pharm Sci 2015;7:329-31.

16. Aggarwal D, Sharma M, Singla SK. The role of natural antioxidants as potential therapeutic agent in nephrolithiasis. Asian J Pharm Clin Res $2013 ; 6: 48-53$

17. Sayana SB, Khanwelkar CC, Nimmagadda VR, Chavan VR. Antiurolithic activity of aqueous extract of roots of Cissampelos pareira in albino rats. Asian J Pharm Clin Res 2014;7:49-53.

18. Wahab S. Authentication and quality evaluation of an important ayurvedic drug Averrhoa carambola Linn Leaves. Asian J Pharm Clin Res 2013;6:52-6.

19. Ravana L. Arkaprakasha. $3^{\text {rd }}$ ed. Varanasi, India: Chaukambha Krishnadas Academy; 2011.

20. Rahul U, Hussain G, Ganti BY. Pharmaceutical review of Arka Kalpana. Int Ayurvedic Med J 2014;2:1113-20.

21. Gaud SD, Nighantu S. Reprinted edition Varanasi: Chaukhamba Vidyabhawan; 2002. p. 431, 141, 87.

22. Trikamji Acharya VY. Sidhiyog Sangrah. Ch. 18. Nagpur, India: Sh. Baidyanath Ayurveda Bhawan Limited 2003. p. 99.

23. Krishnanad S. Rasatantra Sara Va Siddha Prayoga Samraha $16^{\text {th }}$ ed. Ajmer, India: Krishan Gopal Ayurveda Bhawan; 2003. p. 219.

24. Zhang J, Wider B, Shang H, Li X, Ernst E. Quality of herbal medicines: Challenges and solutions. Complement Ther Med 2012;20:100-6.

25. Patra KC, Kumar KJ, Suresh P. Standardization of a polyherbal Siddha formulation, Amukkara Choornam. Indian J Tradit Knowl 2009;8:449-e52.

26. Lohar DR. Protocol for testing of Ayurvedic, Siddha and Unani medicines. Ghaziabad: Pharmacopoeial Laboratory for Indian Medicine, AYUSH. Ministry of Health and Family Welfare. Government of India; 2011. p. 25.

27. Satheesh NV, Upadhyaya K, Bisht A. Phytochemical screening and standardization of polyherbal formulation for dyslipidemia. Int J Pharm Pharm Sci 2011;3:235e8, 17,18.

28. Thakkar R, Baghel DS, Singh S. Physicochemical screening of Godanti Bhasma: An effort to pharmaceutical standardisation. J Pharm Res 2017;11:887-94

29. Sharma S, Baghel DS, Singh S, Singh SK. Dosage form development and preliminary physicochemical characterization of Trikantakadi Kvatha. Asian J Pharm Clin Res 2017;2017:52-6.

30. Sharma R, Amin H, Galib, Prajapati PK. Validation of standard manufacturing procedure of Guduchi satva (aqueous extract of Tinospora cordifolia (Willd.) Miers) and its tablets. Anc Sci Life 2013;33:27-e34.

31. Jain V, Swarnlata S, Saraf S. Spectrophotometric determination of piperinein trikatu churna: An ayurvedic formulation. Asian J Chem 2007; 19:5331-5. 
32. Almeida RM, Pantano CG. Structural investigation of silica gel films by infrared spectroscopy. J Appl Phys 1990;68:4225-32.

33. Ahmed S, Hasan MM, Mahmood ZA. In vitro urolithiasis models: An evaluation of prophylactic management against kidney stones. J Pharmacogn Phytochem 2016;5:28-35.

34. Rajeshwari P, Rajeswari G, Jabbirulla S, Vardhan IV. Evaluation of in vitro anti-urolithiasis activity of Convolvulus arvensis. Int $\mathrm{J}$ Pharm Pharm Sci 2013;5:599-601.

35. Agarwal K, Varma R. In-vitro Calcium oxalate crystallization inhibition by Achyranthes aspera L. and Bryophyllum pinnatum Lam. Br J Pharm Res 2015;5:146-52.

36. Rupam VP, Khan ND, Khan ZH, Mular SM. Study on in vitro antiurolithiatic activity of Bryophyllum pinnatum and Ocimum gratissimum leaves. Biosci Discov 2017;8:290-4.

37. Priya K, Gazala H, Reshma SM, Govindan ND. Pharmaceutico analytical study of Vacha arka. J Biol Sci Opin 2013;1:314-6.

38. Atmani F, Khan SR. Effects of an extract from Herniaria hirsuta on calcium oxalate crystallization in vitro. BJU Int 2000;85:621.

39. Kok DJ, Papapoulos SE, Blomen LJ, Bijvoet OL. Modulation of calcium oxalate monohydrate crystallization kinetics in vitro. Kidney Int 1988;34:346-50.

40. Rao GD. Practical Pharmaceutical Analysis. $1^{\text {st }}$ ed. Delhi: Publisher Birla publications (Regd) Pvt. Ltd.; 2007. p. 137-8. 